\title{
FORUM
}

Submitted 09.01.2015. Approved 02.16.2016

Evaluated by double blind review process. Scientific Editors: Glenn Morgan, Marcus Vinícius Peinado Gomes and Paola Perez-Aleman

DOI: http://dx.doi.org/10.1590/So034-759020160403

\section{TRAJECTORIES OF TRANSNATIONAL MOBILIZATION FOR INDIGENOUS RIGHTS IN BRAZIL}

\author{
Trajetórias da mobilização transnacional pelos direitos indígenas no Brasil \\ Trayectorias de movilización transnacional para los derechos indígenas en Brasil
}

\begin{abstract}
While research on episodes of transnational activism has advanced substantially in recent years, our knowledge about how long-term trajectories of cross-border activism affect the formation of national social movements and their capacity to influence domestic institutional change is still limited. This paper addresses this gap by analyzing transnational mobilization around the political and economic rights of indigenous groups in Brazil. We show that early pathways of transnational mobilization generated a set of ideational, organizational and institutional outcomes that enabled previously marginalized actors to shape the directions of institutional change within the country at the time of the Brazilian democratic transition. We identify three initially uncoordinated trajectories of transnational mobilization taking place in the late 1960 s and 1970 s and show how they converged over time through two social mechanisms institutional cross-referencing and social networking - to form an increasingly tightly knit inter-sectoral social movement that was capable of influencing institution-building during the period of the National Constitutional Assembly (1987-1988). We conclude with a discussion of the linkages between transnational activism and national social movement formation.
\end{abstract}

KEYWORDS | Transnational mobilization, mobilization trajectories, movement formation, indigenous rights, social movements.

\section{RESUMO}

Embora as pesquisas sobre episódios de ativismo transnacional tenham avançado substancialmente nos últimos anos, nosso conhecimento acerca de como as trajetórias de longo prazo do ativismo transfronteiriço afetam a formação de movimentos sociais nacionais, bem como de sua capacidade de influenciar mudanças institucionais domésticas, ainda é limitado. Este artigo aborda esta lacuna ao analisar a mobilização transnacional em torno dos direitos políticos e econômicos de grupos indígenas no Brasil. Mostramos que os caminhos iniciais da mobilização transnacional geraram um conjunto de resultados ideacionais, organizacionais e institucionais, os quais permitiram que atores anteriormente marginalizados moldassem as direções das mudanças institucionais dentro do país no período da transição democrática brasileira. Identificamos três trajetórias inicialmente não coordenadas de mobilização transnacional ocorrendo no final dos anos 1960 e 1970, e mostramos como elas convergiram, com o tempo, através de dois mecanismos sociais -o cruzamento de referências institucionais e a formação de redes sociais - para formar um movimento social intersetorial cada vez mais fortemente entrelaçado, o qual foi capaz de influenciar a formação de instituições durante o período da Assembleia Nacional Constituinte (1987-1988). Encerramos o artigo com uma discussão sobre as ligações entre o ativismo transnacional e a formação de movimentos sociais nacionais.

PALAVRAS-CHAVE I Mobilização transnacional, trajetórias de mobilização, formação de movimentos, direitos indígenas, movimentos sociais.

\section{RESUMEN}

Mientras la investigación de episodios de activismo transnacional ha avanzado significativamente en los últimos años, nuestro conocimiento acerca de cómo las trayectorias a largo plazo de activismo transfronterizo afectan la formación de movimientos sociales nacionales y su capacidad de influir en el cambio institucional aún es limitado. El presente artículo trata esta laguna al analizar la movilización transnacional en torno a los derechos políticos y económicos de grupos indígenas en Brasil. Mostramos que salidas tempranas de movilización transnacional generaron un conjunto de resultados de ideas, organizacionales $e$ institucionales que permitieron que actores marginalizados previamente le dieran forma a los rumbos del cambio institucional dentro del país en la época de la transición democrática brasileña. Identificamos tres trayectorias inicialmente descoordinadas de movilización transnacional transcurriendo a fines de la década de 1960 y 1970 y mostramos cómo convergieron con el paso del tiempo a través de dos mecanismos sociales (referencia cruzada institucional y redes sociales) para formar un movimiento social intersectorial cada vez más compacto capaz de influir en la formación de la institución durante el período de la Asamblea Constitucional Nacional (1987-1988). Concluimos con un debate de los vínculos entre activismo transnacional y la formación de movimientos sociales nacionales.

PALABRAS CLAVE / Movilización transnacional, trayectorias de movilización, formación de movimientos, derechos indígenas, movimientos sociales. 


\section{INTRODUCTION}

Until the late 1960s, indigenous peoples in Brazil were largely invisible in international debates and national decision-making arenas. Despite the human rights violations that affected these groups and their relegation to the ranks of second-class citizens, little was known in the world about their plight. This is not surprising, given that in Brazil indigenous peoples were both economically marginalized and politically disenfranchised. Under the tutorship regime, indigenous societies progressively saw their land taken from them and transformed into pastures and crops. Isolated by means of an institutional framework that sought to silence their claims and eradicate their indigenous identities, their voices could not travel far.

Fast-forward to the early 1980 s and we find that the situation is remarkably different. By this time, a visible, vocal and effective social movement had emerged defending the rights and interests of indigenous peoples in Brazil. In the early 1980s, as Brazil transitioned out of military dictatorship and into democracy, this tightly knit inter-sectoral movement was capable of participating in the construction of a new legal regime governing indigenous rights in the country. Within the National Constitutional Assembly (1987-1988), this movement formulated and defended its institutional proposals, mobilized with other social movements and leveraged support of politicians. Their efforts were not in vain: the Constitution of 1988 recognized, for the first time in Brazilian history, the right of indigenous peoples to their culture and identity as well as their capacity to represent their own interests without the mediation of the state.

The stark contrast between the state of pro-indigenous mobilization in the late 1960 s and in the early 1980s raises important theoretical and empirical questions about the sources of these transformations. These contrasts are especially remarkable given that the emergence of a pro-indigenous movement occurred within an authoritarian political context, where opportunities for activism were severely limited. Add to this that indigenous mobilization was especially thwarted by the institutions that governed indigenous interactions with the state and the question of how a social movement consolidated itself in this context becomes even more puzzling.

While researchers have investigated the formation of pro-indigenous mobilization in Brazil, they have left important aspects of this process underexplored. On the one hand, some authors have focused their attention on the national dimensions of movement formation, investigating the domestic actors, arenas and opportunities for pro-indigenous mobilization in the country (Bittencourt, 2007; Warren, 2001). While this literature links the emergence of these collective actors to transformations occurring within the national political arena in the 1970s, it fails to account for the role played by transnational linkages in the formation of those very arenas and actors.

On the other hand, researchers who do recognize the importance of transnational linkages within the pro-indigenous movement focus on a later stage of mobilization, in which a domestic social movement is already in place and is capable of reaching out into global arenas in order to leverage support for its cause (Brysk, 2000). While recognizing the importance of mobilization across borders for the pro-indigenous movement in Brazil, this approach takes for granted the existence of national collective actors and does not account for the processes through which they came into being. Furthermore, it reduces a multiplicity of transnational processes into a single dynamic that of indigenous activists projecting themselves into the global arena - and falls short of examining the multiple trajectories through which transnational activism affected mobilization at the local and national levels.

Together, these literatures have failed to look at the transnational origins of social movement formation and have not linked transnational activism to the development of sustained proindigenous mobilization. In this paper, we address these gaps by analyzing the mechanisms through which cross-border activism contributed to the formation of a pro-indigenous movement in Brazil between 1968 and 1988. To do this, we draw on recent literature that explores the transnational origins of national social movements (David, 2007) and argue that transnational linkages were not only important for the amplification of existing identities, grievances and claims of indigenous groups and pro-indigenous organizations situated in Brazil; they were crucial in the development of those identities, grievances and claims. Furthermore, we contend that it is problematic to reduce transnational mobilization to a single process. In order to understand the influence of cross-border activism upon domestic movement formation, it is necessary to examine multiple and interacting processes of transnational mobilization - processes we refer to as trajectories of mobilization - and analyze how they contribute to the development of collective actors within the domestic arena.

Our analysis pays close attention to actors and organizations which have been largely ignored in studies of transnational activism. These rooted transnationalists (Djelic \& Quack, 2010; Tarrow, 2005) include members of the Catholic Church, secular missionaries and public anthropologists in exile who were central figures in the development of pro-indigenous mobilization in Brazil. Initially situated within different trajectories of mobilization, these actors bridged across trajectories as they sought to transform the field of indigenous rights. It was at the interface and convergence of 
these trajectories that a national social movement emerged, and by analyzing the mechanisms through which convergence occurred, we render a more comprehensive account of how transnational collective action influences the formation of social movements at the local and national levels.

\section{FROM MOBILIZATION ACROSS BORDERS TO NATIONAL SOCIAL MOVEMENTS}

While there has been a fair amount of research done on the transnationalization of social mobilization and, more generally, on shifts in the scale of activism from the local to the global levels and vice-versa (Tarrow \& McAdam, 2005), we know less about how transnational activism can create conditions for sustained mobilization on local and national levels, and ultimately converge into the formation of sustained social movements embedded and active within domestic arenas (David, 2007). Research has shown that transnational activism has provided crucial channels for amplifying the grievances and claims of collective actors situated within unresponsive political contexts (Brysk, 1993; Keck \& Sikkink, 1998). But how does mobilization across borders affect the very formation of those collective actors and influence opportunities for sustained mobilization within unfavorable political contexts?

In order to answer these questions, we draw on theoretical frameworks that allow us to explore the development of mobilization within cross-border networks and multi-layered contexts of action. In this section, we present three theoretical building blocks of our analysis, namely: (1) a longitudinal framework which places mobilization and its outcomes in the flow of time; (2) the concept of transnational linkages, which allows us to closely investigate the relational characteristics of crossborder ties; and (3) a multi-layered conception of opportunities for mobilization which takes into account that transnational activists are usually embedded in multi-level institutions and arenas.

\section{Social movements and outcomes of contention in time: Studying trajectories of mobilization}

In recent times, there have been many calls for the adoption of a more longitudinal perspective in the field of transnational activism (Bülow, 2010; Zajak, 2014). The argument put forward by these researchers is that the focus of the literature on events such as protests or campaigns leads to a partial understanding of transnational collective action. In addition to lacking a broader sense of the field within which contention occurs, these studies "may lead to an overly optimistic analysis about the sustainability and the impacts of transnationalism" (Bülow, 2010, p. 23). A longterm perspective allows us to analyze the dynamic interaction between social movements and the impacts of mobilization and to grasp how, in the unfolding of contention, the latter become the building-blocks with which mobilized actors can construct projects, strategies as well as collective identities.

In order to analyze the shifting trajectory of actors and organizations involved in transnational contention, Bülow (2010) developed the concept of pathways to transnationality, defined as "routes taken by civil society organizations to link debates and action across scales" (Bülow, 2010, p. 6). Zajak (2014) shares the focus on long-term transnational trajectories in her study of transnational pathways of influence, defined as the routes taken by activists in order to affect institutional change. By situating mobilization within the flow of time, these longitudinal approaches push us to revisit our understanding of how mobilization impacts and changes its contexts of action (Giugni, 1998). Instead of conceptualizing outcomes of mobilization as static effects of instances of mobilization - for instance, analyzing an instance of legal change as a finished outcome of collective action -, longitudinal frameworks enable researchers to set interaction between outcomes and mobilization in motion. They recast movement outcomes as partial consequences of collective action, which gain significance as further mobilization unfolds.

Outcomes of mobilization can therefore become many things: they may be forgotten or may remain inaccessible to other actors (Schneiberg, 2007); they may become the trigger for demobilization or coutermobilization; or they may serve as input for the emergence of new action repertoires. Furthermore, outcomes of mobilization can be used as an instrument for the construction of movement coallitions and identities. Actors situated within distinct trajectories of mobilization can come to see themselves as involved in a common cause as they interpret, activate and deploy the outcomes ensuing from other trajectories, thereby using movement outcomes into an instrument of coallition formation and collective identity-building.

\section{Transnational activism: From global and local positions to transnational linkages}

One of the key questions addressed by studies on transnational collective action concerns the type of tie that connects actors and organizations situated across borders. While some authors tend to view the interaction between global and local arenas as vertical and asymmetric (Boli \& Thomas, 1999; Keck \& Sikkink, 1998), others have called for a more horizontal approach to the study of cross-border mobilization (Ferguson, 2006; Matsuzawa, 2011). What these approaches have in common is that they maintain an 
analytical divide between global and local levels of mobilization. However, actors operating transnationally are not exclusively bound to any single arena and typically have multiple affiliations, including local and global ones. It is precisely this combination of affiliations that matters, since the multiplicity of embeddedness allows for the flow of ideas, resources and strategies across national divides, generating creativity and novelty.

In order to bridge across the local-global conceptual divides, we move beyond both vertical and horizontal conceptions of transnational mobilization and adopt a rooted transnationalism approach, under which we subsume scholarly work that has questioned the binary allocation of social movement actors, their goals, strategies, and identities to either the local or the global (Alonso, 2009; Djeclic \& Quack, 2010; Tarrow, 2005). This literature has shown that actors and organizations can have multiple affiliations, being embedded in organizations, networks and experiences that span across borders. Based on these insights, it becomes important to investigate the types of linkages that connect across levels and institutional spheres of mobilization. What types of action are involved in these linkages, and what relationships bind actors across levels of mobilization? Stark, Vedres, and Bruszt (2006) address these questions by investigating the relationships between forms of transnational ties and domestic rootedness of civic organizations, finding that the patterns of connectedness across levels of mobilization result in different types of transnational publics.

Transnational linkages can serve as circuits for the circulation of material and non-material resources, they can be characterized by ties of participation or accountability, of cooperation or competition, and all of this matters when analyzing the possible effects of transnational mobilization on the formation of national movements. Furthermore, the characteristic patterns of transnational linkages can change over time, leading to shifts in the publics formed by interacting actors and organizations. These shifts are, in turn, important for analyzing changes in patterns of mobilization over time. In order to analyze them, it is important to adopt an analytical framework that moves beyond an investigation of episodes of transnational contention to a framework that places contention more fully in the flow of time.

\section{Shifting linkages and contexts of action: Opening up opportunities for mobilization through transnational activism}

The concept of political opportunity structures coined by political process theorists has recently come under a twofold attack. Firstly, it has been criticized for being overly structuralist and not paying sufficient attention to how political contexts themselves can be affected by mobilization (Goodwin \& Jasper 1999). Secondly, authors studying processes of mobilization beyond the nation state have asserted that "the concept of political opportunity structures has been developed with domestic social movements, nation-states and national policies in mind" (Gavarito, 2007, p. 153) and lacks conceptual tools to integrate global and transnational opportunity structures into the analysis.

More recently, the issue of state-centrism in the analysis of opportunities for mobilization has been tackled by researchers working from within social movement theories and international relations. These authors argue that a model of multi-level and nested political opportunity structures can lead to a better understanding of how activists mobilize by "using political opportunities at one level in order to create political openings at another level” (Risse \& Sikkikk, 1999; see also Meyer, 2003). Conceptualizing opportunities for mobilization as multi-layered contexts significantly adds to our understanding of the emergence and effects of social movements (Schneiberg \& Lounsbury, 2008). But in order to understand how multi-level opportunity structures affect the capacity of actors to mobilize across settings and levels, the concept of transnational linkages is crucial. It is through these linkages that ideational, organizational and institutional resources can flow across borders and thereby shift the contexts in which mobilization takes place.

As organizational resources are channeled across networks, new organizations emerge and forge links within their contexts of action. And if these linkages bridge across institutional sectors and into the state, new alliances and openings are consolidated for challenger movements and thus the opportunities for mobilization emerge. In a setting where domestic political opportunities are closed, transnational linkages which support the flow of resources and information into domestic settings may become an important driver of movement formation.

In the remainder of this article, we apply this concept of cross-border mobilization within multi-layered opportunity spaces. We identify three trajectories of transnational mobilization that lie at the origins of the indigenous movement in Brazil and explore the mechanisms through which these pathways converged into a sustained process of pro-indigenous mobilization throughout the 1970s. We use the terms trajectories and pathways synonymously, to describe a directional process in which sequences matter but that is non-deterministic and open ended.

\section{MATERIALS AND METHODS}

Our investigation of transnational mobilization for indigenous rights in Brazil is based on a set of materials that include 
primary documents, semi-structured interviews and literature. We used different sets of materials to trace the development and consequences of each trajectory of mobilization described below and to trace the linkages and connections that were forged amongst them.

The reconstruction of the first trajectory of mobilization relied on interviews with anthropologists engaged in criticizing Brazilian indigenism and anthropological practice throughout the 1970 s and 1980 s, as well as on the public declarations issued by these anthropologists and on the anthropological studies demanding indigenous land rights they produced in the early years of the Brazilian indigenous movement. To reconstruct the second trajectory, we relied on minutes of the National Assemblies of Indigenous Chiefs and declarations issued at meetings of bishops and missionaries in Latin America between 1968 and 1988. We also conducted interviews with missionaries that were directly involved in the reform of indigenous missionary practice at the time in order to understand the motives and strategies of these actors in engaging in the field of indigenism. The case study also draws on a comprehensive literature review of official and grey publications in Portuguese and English. Finally, our account of the third trajectory of transnational activism is based on official documents of the Brazilian government, on international media reports and on statements of international organizations issued in the late 1960 s denouncing abuses in Brazilian indigenous policy.

We applied process-tracing techniques to these materials in order to trace and analyze the development of the three trajectories of mobilization and to reveal the mechanisms through which each of them impacted change in the institutional contexts of action. In this process tracing, we paid special attention to the intersection and linkages between the three trajectories, and to the processes through which they converged in impacting change in the institutions that govern indigenous economic and political rights in Brazil from 1968 until 1988.

\section{MULTIPLE TRAJECTORIES TOWARDS THE CONSOLIDATION OF A NATIONAL MOVEMENT FOR INDIGENOUS RIGHTS IN BRAZIL}

Until the late 1960 s, the emergence of an organized indigenous movement in Brazil was inhibited by the institutional regime governing indigenous groups in the country, called indigenous tutorship. Enacted through a set of laws in the early $20^{\text {th }}$ century, indigenous tutorship was a nation-building institution oriented towards the state-directed assimilation of indigenous peoples (Diacon, 2004; Lima, 1995). Tutorship was rooted in the assumption that indigenous groups would progressively be civilized and integrated into society. Until then, the state would be responsible for administrating the lives, lands, and resources of these groups. From 1928 until 1967, tutorship was exercised by a federal indigenist bureaucracy called the Serviço de Proteção ao Índio (Indian Protection Service [SPI]), superseded in 1967 by the Fundação Nacional do Índio (National Indian Foundation [FUNAI]). The indigenist bureaucracy was supposed to provide fraternal protection to the Indians by protecting them from the brutality of the development frontier. At the same time, it was to ensure the expansion of that very frontier. Caught between these contradictory goals, the bureaucracy intervened by removing the Indians from their territories and transferring them into small plots of land called indigenous reservations (Cordeiro, 2013; Oliveira, 1988). Once the Indians had been concentrated within the reservations the indigenist bureaucracy had the authority to govern their resources and dictate the rhythm of their lives. The only actors allowed to participate in the governance of indigenous groups were religious missionaries, who collaborated with the state in civilizing indigenous groups (Benites, 2014; Prezia, 2003).

The alliance between missionaries and state made it difficult for any sustained critique of indigenist policies to emerge at the domestic level, especially in the closed and authoritarian political context of the Brazilian military dictatorship (1964-1985). In order to explain the formation of an organized national indigenous movement, we must shift our attention away from isolated local instances of resistance towards a more comprehensive analysis of trans-local networks of activism. From the 1960 s onwards, a number uncoordinated processes of contestation against tutorship emerged within different transnational networks and organizations. In the course of the 1970s, the critiques formulated within these arenas contributed to the formation of a pro-indigenous movement in Brazil that became a driving force for the establishment of new rights for indigenous peoples in the country.

In the following sections, we analyze these three trajectories of transnational activism for indigenous rights and show how they became increasingly interconnected, helping to form a national pro-indigenous movement in Brazil. Each trajectory is characterized by a distinct set of actors mobilizing transnationally through different means and with different outcomes. Each trajectory contributed in incremental ways to pro-indigenous mobilization in Brazil in the 1970 s and 1980 s. We refer to them as 1) the trajectory of transnational public anthropologists; 2 ) the trajectory of liberation theology missionaries; and 3) the trajectory of international journalists and information politics. 
We begin by presenting and describing the development of these three trajectories from the late 1960 s to the early 1980 s. Following this description, we discuss two social mechanisms - institutional cross-referencing and social networking - which increasingly connected and combined different trajectories into a nation-wide mobilization for indigenous rights in the National Assembly, where the new Federal Constitution of Brazil was discussed from 1987 to 1988 . The main events described in each trajectory as well as the two social mechanisms through which the latter converged into a broad-based pro-indigenous movement in Brazil in the late 1970s are illustrated in Figures 1 and 2.

\section{First trajectory: Transnational activism of anthropologists and the emergence of local indigenous support organizations}

In the 1950 s and 1960 s, anthropologists working with indigenous communities in Brazil became increasingly skeptical of the efficacy and morality of tutorship. The indigenist policies of the SPI came increasingly under scrutiny of anthropologists many of them working from within the agency - who idealized profound transformations in the indigenist bureaucracy. These anthropologists had entered the cadres of the SPI in the $1940 \mathrm{~s}-1950 \mathrm{~s}$ imbued with knowledge of contemporary anthropology and avid for change. Darcy Ribeiro, an anthropologist who worked for the SPI between 1949 and 1956, elaborated important critiques towards tutorship and its aftermath, especially concerning the disastrous consequences that the institution had upon Indigenous groups (Ribeiro, 1970). Many of these idealist anthropologists left the organization in the late 1950 s as its corruption and abusive practices towards indigenous populations became increasingly obvious.

In the late 1960s, Georg Grünberg, an Austrian anthropologist who conducted fieldwork amongst the Kayabi Indians in Brazil, witnessed firsthand the violence of frontier expansion and the inability of the indigenist bureaucracy to protect the Indians. Grünberg saw a war between the patrons of rubber tapping and the Kayabi Indians, forced to flee to the recently instituted Xingu National Park (Grünberg, 2015). Like Ribeiro, Grünberg became dedicated to denouncing the shortcomings of South American indigenist policies and idealizing alternative models of indigenism for the continent. Ribeiro and Grünberg's work is representative of a broader set of anthropological critiques against the foundations and practices of indigenous tutorship that developed at the time. However, following the military coup in 1964 and the establishment of military dictatorship, it became very difficult and dangerous to articulate such critiques in Brazil. In the years that followed the coup, political parties were banned, political organizing was restricted, and public debate was subjected to censorship. Many critical Brazilian anthropologists had to leave their country and go into exile. This is precisely what happened to Ribeiro, who first sought refuge in Uruguay, then in Venezuela.

At this time, an informal transnational network of roughly two dozen politically engaged anthropologists scattered throughout Latin America (and to some extent also Europe) emerged. Many of them, like Ribeiro, had been sent into exile by their authoritarian governments, and they shared a deep critique of South American indigenism as well as a will to transform it. Austrian anthropologist Grünberg was one of them. Upon returning from fieldwork in Brazil to Europe, he pursued the idea of setting up a forum where anthropologists with critical perspectives on Latin American indigenism would be able to engage in joint action against indigenous policies in the continent. These ideas took form in 1970, when Grünberg had a fortuitous encounter with the coordinator of the World Council of Churches (WCC) Program to Combat Racism. The program had been instituted to intervene in the context of South African apartheid, but Grünberg convinced the coordinator that the WCC should get involved in South America. They decided to organize a gathering where anthropologists with experience in South America would be able to exchange information and develop a project for intervention. This was the birth of the Barbados Symposium on Interethnic Conflict in NonAndean South America.

In 1970, Grünberg traveled to South America and across the continent with the support of the WCC issuing invitations, discussing the project, and consolidating the guiding principles of the gathering. According to Grünberg,

In those times the anthropologist that had long and rich experiences in the field formed almost automatically a network, in the sense that they were constantly meeting each other in international conferences and that they also needed to find refuge in face of military persecution. So there was a culture of mutual assistance and support, because we had always been considered communists by the military, subversives, and we were seen as people who wanted to turn Indians into subversive elements against the state. So there was a quite practical sense of fraternity, because we many times had to disappear from our countries and seek exile elsewhere. In Paraguay you found exiled Argentinians, in Argentina you found Uruguayans... so there was a personal network that formed 
among these two dozen field anthropologists who were set on speaking out and who were insisting that we could not go on with internal colonialism and that it had to end. And it was not hard for us to find each other - if you knew three of us then you knew us all, at least by name. (Grünberg, 2015)

The First Barbados Symposium took place in 1971 at the University of the West Indies in Bridgetown. It was attended by 19 anthropologists from 12 countries, all of whom had conducted field research in South America. At the end of the Symposium, these anthropologists signed a declaration outlining the responsibility of the State, religious missions and anthropology in the genocide of indigenous groups throughout South America (Bartolome et al., 1971). The Barbados Declaration was a landmark document. It articulated severe critiques against Latin American indigenism, and proposed the liberation of indigenous peoples through processes that they themselves would conduct (Bartolome et al., 1971).

Following the Symposium, some anthropologists returned to South America in order to implement this new indigenism. In 1974, Grünberg traveled to Paraguay where he founded an organization called the Pai Tavyterã Project (PPT), which would allow indigenous groups to determine the goals, priorities and means of organization and activism; the PPT's staff would support the endeavors of the local communities (Grünberg, 2015). This model of support organization soon spread into Brazil, where one of PPT's interns, Rubem Thomaz de Almeida, founded the Kaiowá Ñandevá Project (PKN) in 1976 (Almeida, 2001). These organizations were pioneers in experimenting with a new form of indigenism, in which the anthropologists would intervene only as requested to by the indigenous communities, serving as mediators between the village, surrounding society and the state. The PKN was pioneer in introducing foreign funding into the field of pro-indigenous activism in Brazil. The relationship between public anthropologists and the ecumenical axis of Christian Churches enabled them to get funding from international organizations such as the World Council of Churches, Bread for the World and Misereor (Almeida, 2001; Grunberg, 2015).

These new ways of organizing and financing activism flourished in the late 1970s. At the time, pro-indigenous activists took advantage of shifts in the domestic political landscape - which was slowly showing signs of opening - in order to promote a broad-based wave of mobilization against the indigenist policies of the military government. The latter was planning to issue a decree liberating indigenous groups from the constraints and entitlements of tutorship. This was called the "emancipation decree". As seen above, the tutorship regime held that indigenous groups would one day become assimilated into the national society, and emancipation was the legal act that would formalize the conclusion of this transition. Emancipated peoples would no longer be classified as indigenous and would therefore not have the special rights and restriction supported by the latter. The Interior Minister defended emancipation as a means of ensuring the full integration of indigenous peoples in the country. Yet, pro-indigenous activists interpreted it as a measure promoted by government in order to evade its obligation to demarcate indigenous lands. Mobilization in the mid-1970s against indigenous emancipation propelled the proliferation of support organizations throughout Brazil.

Between 1977 and 1980, numerous indigenous support organizations sprung up in various regions. By the mid-1980s, there were over 20 indigenous support organizations active in the country. While some activists followed the model of the PKN in setting up community-based support organizations where the activists would share the livelihoods of indigenous groups, others took the model of indigenous support organizations into the urban centers of Brazil. Even if there were variations among the specific forms and engagements of these organizations, they were all rooted in the idea of the transformation of indigenism formulated by the Barbados Declaration. While their engagements were decidedly local, these organizations maintained their linkages to transnational organizations, to which they reported and from which they received ongoing flows of resources.

The indigenous support organizations were central in an emerging pro-indigenous political field. The grassroots support organizations were important in backing local political organization of indigenous groups and thoroughly documenting local claims of indigenous groups - especially claims for land demarcation. Meanwhile, their later urban versions gave visibility to the indigenous cause in the large Brazilian cities and bridged across indigenous claims and the broader movement for democratization that was taking place in Brazil in the late 1970s. Furthermore, it was the anthropologists who brought the existing regulation of indigenous land rights to life - particularly the Indigenous Statute of 1973 - by providing their academic expertise for the demarcation of indigenous territories and supporting the claims of indigenous groups towards the state administration.

In sum, the network of transnational anthropologists contributed to the transformation of indigenist institutions in three ways. First, their embeddedness in personal networks that spanned across borders provided them the supra-national platform and resources necessary to develop, formalize and divulge a landmark critique of South American indigenism despite the authoritarian political landscape that plagued the region at the time. Second, the Barbados experience inaugurated linkages between public 
anthropologists and foreign organizations able to finance their projects. Through these same transnational anthropologists, the critiques, projects and resources of the Barbados Convention could trickle down into Brazil, at first discretely and sporadically but later with increased intensity, into pro-indigenous activism within the nation state. This occurred through the inauguration of a new organizational form - the indigenous support organizations which, despite their different forms of engagement, all drew on the ideals, principles and practices of Barbados in order to support the claims of indigenous groups and improve their livelihoods. Through these organizations, the anthropologists could connect with other professionals, support the emerging indigenous movement and advance indigenous claims for land demarcations and other rights.

\section{Second trajectory: Transnational networks of liberation theology missionaries and the emergence of a national movement}

Until the 1960s, the common practice of Catholic and evangelical missionaries was to work hand in hand with the indigenist bureaucracy, baptizing and converting indigenous groups against their will and leading them into the state-sponsored reservations (Almeida, 2001; Prezia, 2003). These practices became increasingly subject of criticism from inside both Churches for their disruptive effects on indigenous livelihoods. Drawing on the ecumenical directives and inter-cultural spirit of the Second Vatican Council (1962-1965), progressive groups within the Catholic Church were trying to make the institution more directly engaged with the emancipation of marginalized sectors of the population, including landless peasants, dwellers of urban peripheries, and ethnic minorities. Within the Latin American Catholic Church this movement became known as liberation theology (Smith, 1991). These reformist actors met at the 2nd Conference of the Latin American Episcopate (1968), where they coined a joint statement affirming that:

For the vast sectors of marginalized men, the goal of education should not consist in incorporating them into the cultural structures which surround them, which can be equally oppressive. Its goal should be to build their capacity to, themselves, as agents of their own progress, develop, in their creative and original way, a cultural world that mirrors their own richness. And, especially with regards to the Indians, it is necessary to respect their own cultural values. (Latin American Episcopal Council, 1968)
The intervention of the Church in the lives of Indigenous communities was subsequently discussed in meetings of the Latin American Episcopal Council (Celam). This indicates that missionary intervention in Latin America was, as of the late 1960 s, extensively debated in transnational fora of the Church. Between 1968 and 1994, over 50 of such events took place in South America (Prezia, 2003, pp. 335-338). Internal criticism of missionaries was significantly fueled by the Barbardos Declaration of the anthropologists published in 1971 which directed harsh attacks towards missionary practice and called for the suspension of all missionary activity to save the moral integrity of all Churches involved.

In Brazil, the vocal outcry of the Barbados Declaration against Christian missionaries fueled the engagement of reformist sectors of the Church and aggravated the incipient crisis of missions in Brazil, which were being questioned for their ongoing practices of mass baptism, conversion, and complicity with the state in genocidal practices. It was in this context that the Indigenous Missionary Council (CIMI) was founded in 1972 (Suess, 1989). Proposed by a group of progressive Jesuits, CIMI was to be the umbrella organization unifying and supervising Catholic missions all over Brazil in a way that respected principles of the Second Vatican Council. CIMI was in part a response to the Barbados Declaration, and a demonstration that the Church was willing to transform its missionary practice. According to Egon Heck, a CIMI missionary who has been engaged in the organization since its foundation in 1972 ,

CIMI was born first from the frustration felt by a group of missionaries regarding their presence and engagement among indigenous peoples. Secondly, it was born from a context in which the Catholic Church was becoming more open to social issues, as can be seen from the Second Vatican Council. So it was this context of transformations within the Church and frustration amongst missionaries that led to the foundation of CIMI. I could also add a third factor: the emergence of conflicts within society in general concerning the dictatorial and authoritarian context of the time (...). The organization positioned itself as an articulation of missionaries fighting for the transformation of the Catholic Church concerning the Indians, and contributing to a broader transformation within Brazilian society so that it would finally be able to recognize its plurinationality. (Heck, 2014) 
In 1974, CIMI began a process of political organization that spanned from the local to the international level. Locally, missionaries would monitor and report on the conditions of indigenous groups, provide material support for communities undergoing hardship and inform indigenous groups of their rights. If a group wanted to resist eviction or reclaim a territory, CIMI would provide food, transportation and media visibility to their struggle, as well as political training to their leaders (Silva, 2012). CIMI promoted political education workshops with indigenous chiefs and also organized regional assemblies where indigenous leaders could come together to discuss the grievances of their communities.

On the national level, CIMI used its connections to the Church to channel local groups' demands to higher levels of decision-making. They also used the media to report on the situation. In 1976, CIMI founded an independent magazine named "Porantim", through which missionaries and Indians could share their stories, grievances and demands. Organized on a national scale, CIMI was able to collect, compile and compare information about the situation of Indigenous groups all over Brazil. Due to the organization's official connection to the Catholic Church, it was able criticize official indigenist policy in a way that no other organization could. On the local level, CIMI missionaries would cooperate with indigenous groups and anthropologists in order to map out and systematize the land tenure demands of indigenous peoples, taking those demands to Funai and giving them publicity in their specialized media outlets (Silva, 2012).

This production and dissemination of information was crucial for the promotion of public awareness concerning the indigenous question in Brazil. However, CIMl's engagement did not end there. The organization's most important contribution to the transformation of interethnic relations in the country was its continuous and intense support for the development of an organized national indigenous movement. Beginning in 1974, CIMI promoted a series of National Assemblies of Indigenous chiefs. Leaders from around the country were transported with the help of CIMI to the assemblies, where they would receive political training, material support, and incentives to put together an autonomous instance for indigenous politics at the regional and national levels. The indigenous leaders had the chance to share and elaborate on their common grievances, and the main issues brought up at the assemblies were disseminated through declarations, transcriptions and articles in CIMI's newsletter. Between 1980 and 1984, 42 national indigenous assemblies were held throughout the country.

In 1980, 16 of these indigenous leaders gathered in Mato Grosso do Sul and founded the Union of Indigenous Nations - UNI
(Oliveira, 1988, p. 36). According to its statute, the organization sought to "represent the Indigenous Nations and communities which took part in it", "advance the demarcation of indigenous lands" and "promote the autonomy and self-determination of indigenous groups". UNI grew out of the Assemblies of Indigenous Chiefs organized by CIMI since 1974, but its foundation represented the moment in which the Indigenous groups formalized their own instance of representation.

The transnational networks of liberation theology activists contributed in three ways to the transformation of indigenist institutions. First, they combined the new beliefs and practices that were emerging within the Church in the aftermath of the Second Vatican Council with the grounded frustrations of Catholic missionaries in order to formulate an alternative model of missionary engagement in Brazil. This model called for inter-culturalism and cultural recognition, and demanded that missionary engagement not limit itself to the transcendental realm, but also engage with political claim-making. This alternative model of missionary practice gained momentum after the Barbados Declaration and sparked the foundation of CIMI. Second, reformed missionaries were responsible for organizing a national indigenous movement. They did this through the organization of indigenous assemblies and through the political education of indigenous leaders, which would later on found UNI and represent indigenous interest at the Constitutional Assembly of 1987-1988. Finally, by founding specialized media outlets such as Porantim, CIMI helped to gather, systematize and disseminate information about indigenous grievances throughout Brazil, giving the indigenous cause visibility throughout the turbulent process of democratic transition.

\section{Third trajectory: International journalists, transnational information politics and the passage of the Indigenous Statute in Brazil}

With little room for domestic mobilization during the early years of the military regime, an important trigger for domestic legal change in the 1970 s came from international pressure on the Brazilian government (Oliveira, 1985). The protagonists of this third trajectory were journalists writing for international newspapers and non-governmental organizations. Deploying information politics, these protagonists placed pressure on the Brazilian government to review and change its legal treatment of ethnic minorities in the early 1970s. One of their most important sources was paradoxically a report by the Brazilian government, the so-called "Figueiredo Report". This report was the result of one of the many investigative commissions instituted in the 1960 s to investigate charges of corruption and 
abuses within the Indian Protection Service (SPI). Since these charges dated back to the 1950 s and early 1960 s - i.e., before the military dictatorship had been instituted in 1964 - the military government through it could discredit its populist predecessors by looking into the accusations.

The SPI had served as Brazil's indigenist bureaucracy throughout the $20^{\text {th }}$ century. If its official mission had been to assist and protect the Indians in their integration into national society, the agency had, over the decades, significantly distanced itself from this duty, becoming plagued by endemic corruption and human rights abuses (Lima, 1995). Minister of Interior Albuquerque Lima commissioned Attorney General Jader Figueiredo to lead the investigation on the SPI and issue a report on its findings. Figueiredo and his staff traveled over 16,000 kilometers across Brazil, interviewing indigenous agents, missionaries, and Indians. The Commission's report, named "Figueiredo Report", was concluded in 1967 and documented systematic abuses and violence perpetrated by agents of the SPI against indigenous groups (Figueiredo, 1967).

The investigation of the SPI conformed to military efforts to rationalize and moralize bureaucracy to eliminate corruption and leftist infiltration within its cadres (Garfield, 2001, p. 143). More perplexing than the report itself was the government's decision to divulge, rather than stifle, the atrocities revealed in the final document. In March 1968, General Albuquerque Lima held a press conference where he presented the main findings of the report. Several national and international reporters were present at the conference, and a number of others flew into Brazil in its aftermath to investigate the findings. According to Garfield (2001, p. 143), the press conference was a deliberate artifice of the military, engendered to boost its morale and leverage support for its efforts to enforce human rights in the country:

In part, the Figueiredo Report staged a perfect morality play to legitimize authoritarian rule in spotlighting corrosion of the public sector under the populists. Military officials apparently also wagered that in publicizing crimes against Indians they would earn kudos for salvaging Brazil's racial harmony. One month after the release of the Figueiredo Report, the Ministry of the Interior impressed on a skittish Ministry of Foreign Relations that denouncing these atrocities "could only strengthen abroad the Brazilian image with regard to racial democracy" and demonstrate that military rule was 'incompatible, in its spirit, with the process of human degradation. (Garfield, 2001, p. 143)
It did not take long for the decision to divulge the report to backfire. Despite the censorship that prevailed at the time, news reports appeared in the Brazilian media accusing the government of backing genocidal policies. For government opponents within Brazil, the controversy provided the chance to challenge the military and enlist foreign support. The legal opposition party seized the opportunity and threatened to appeal to the United Nations in order to put Brazil's indigenous peoples under international guardianship (Garfield, 2001, p. 144).

But the most prominent consequences of the report took place in the transnational realm (Oliveira, 1985). Journalists working for international media were present at the press conference, and, in its aftermath, a number of foreign observers went to investigate the situation (Davies, 1977). These observers published impacting articles and reports in the international press, including the New York Times, the British Sunday Times and Der Spiegel (Der Spiegel, 1968; Lewis, 1969; Montgomery, 1968). Norman Lewis' piece on the British Sunday Times entitled "Genocide" was especially influential, presenting a thorough description of the institutionalized violence perpetrated against indigenous peoples by the state. Paul L. Montgomery, New York Times bureau chief in Rio de Janeiro from 1966 to 1969, was another international journalist who reported in the New York Times about massacres against Indians.

These reports were "a major source of embarrassment for the new military government of Brazil and produced a momentary wave of protests throughout the world" (Davies, 1977, p. 12). These repercussions sparked the emergence of a new field of international organizations engaged with indigenous peoples in the late 1960 s and early 1970s. In 1969, and as a direct response to Lewis' article, Survival International was founded in the UK with the goal of defending the rights of tribal peoples. In 1972, the anthropologist David Maybury-Lewis and his colleagues founded Cultural Survival to foster the international indigenous rights movements.

The Brazilian government desperately took measures to silence the worldwide condemnation. In 1967, it extinguished the SPI and instituted the National Indian Foundation as its successor. Another response came in the form of a legislative bill dedicated to the regulation of indigenist policy. It received the name of Indigenous Statute (Federal Law 6.001 of 1973). The Bill sought to stifle external disapprobation, demonstrating to international public opinion the positive facet of Brazilian government and its concern with indigenous rights. According to Oliveira, "Luxury editions [of the Statute], with translations to English and French were widely distributed within and outside of the country [while] this text has until this day not been translated to any one of the 200 indigenous languages that exist in Brazil" (Oliveira, 1985, p. 20). 
Discussed and approved during the most repressive period of the Brazilian dictatorship, the Statute constitutes a highly ambiguous legal document, which remains committed to the assimilationist project of the previous institutional framework while also introducing new regulation on indigenous land rights. It was, in fact, the first legislation that contained a systematic regulation of such rights. While the Statute had little immediate impact on the practical life of Indians due to lack of implementation, it became an important institutional reference point for activists seeking to promote indigenous rights in Brazil following its passage up into the 1980 s.

The Indigenous Statute was important in formalizing indigenist policy in the country and providing the pro-indigenous activists with something to work with as well as against. In regulating the land rights of indigenous people, it established a deadline of five years for the government to demarcate the indigenous lands that had not yet been demarcated. This clause was subsequently drawn on by public anthropologists supporting the demarcation of indigenous territories. The Statute was also used to consolidate the pro-indigenous movement and bridge across indigenous groups and urban civil society organizations during the mobilizations against the emancipation decree in the late 1970s. When the government sought to emancipate indigenous groups, pro-indigenous activists drew on the obligations that the Indigenous Statute had stipulated for the indigenous bureaucracy - namely the duty of the state to demarcate all indigenous lands within five years' time - and asserted that the emancipation of Indians could only take place after the obligations of the tutor had been fulfilled.

Overall, the mobilization of journalists writing for international newspapers was important for the consolidation of the indigenous movement in Brazil in two ways. Firstly, it sparked the emergence of an international field of pro-indigenous organizations, which from then on would serve as permanent watchdogs in the field of indigenist policy. Secondly, it resulted in the government's defensive enactment of formal legislation which, despite of its ambiguities, provided important inputs and instruments for the mobilization and consolidation of the Brazilian indigenous movement. The Statute gave publicity to important elements of official indigenist policy, which, previously, had remained only implicit and unarticulated. The emerging pro-indigenous organizations used the Statute to advance the demarcation of indigenous territories in the country, and the rights enshrined in the Statute were instrumentalized in the wave of mobilization against the government's emancipation policy. It was at this moment that various organizations emerged in the pro-indigenous field and a broad based, urban and rural proindigenous movement consolidated.

\section{Converging trajectories}

The sections above described three trajectories of activism that linked different actor groups in Brazil with other actors across Latin America and other continents in the struggle for the transformation of indigenist policies. While the trajectories differ in terms of the main actors, means and outcomes of mobilization, they became increasingly interconnected as mobilization unfolded along each of these trajectories. They also became increasingly locally entrenched and finally built up into a national indigenous movement composed of a Union of Indigenous Nations, secular and religious indigenist support organizations, and professional associations. It is only through tracing both the transnational linkages and the increasing density and diversity of relations between local mobilizations in different places and regions within Brazil that the consolidation of a national indigenous movement and its influence on the Federal Constitution of 1988 can be understood. In this section, we suggest that two social mechanisms, here understood as recurrent processes linking specified initial conditions and a specific outcome (Mayntz, 2004), were crucial for this development: institutional cross-referencing and social networking.

By institutional cross-referencing we mean that actors in one trajectory picked up on the outcomes of activism of other trajectories and wove them together into one broader process of mobilization and institutional change. An example of institutional cross-referencing can be found in the way in which originally marginal liberation missionaries drew on the Barbados Declaration as a rhetorical device to legitimize their new pro-indigenous approach towards the official doctrine of Church and to reform it through transnational linkages with missionaries and bishops across Latin America. Developments following the passage of the Indigenous Statute in 1973 provide another significant example of institutional cross-referencing. Anthropologists, missionaries, and an increasing field of pro-indigenous activists selectively drew on the clauses of the Statute in order to advance indigenous land demarcations and hinder the implementation of government's emancipation policy.

The mechanism of institutional cross-referencing was central to the incremental development of a social movement identity that spanned across institutional sectors. As actors situated within one trajectory of mobilization acknowledged, interpreted and activated the outcomes of other trajectories, they came to see each other as involved in a common cause. For instance, the fact that the Barbados anthropologists had formulated a critique of the Church which was so aligned with the projects of reformist episcopates and missionaries signaled to the latter that they could cooperate in their quest for a reformed 
indigenism. Cross-referencing was a mechanism of approximation between and identity-building across pathways, which allowed them to become increasingly tightly knit in their mobilizations.

By social networking we refer to the increasing density but also diversity of sustained professional, political and personal relationships between previously separately operating actor groups of the different trajectories. Our analysis suggests that while in the early period of mobilization key actors mobilizing along the different trajectories had relatively few and if so episodic relationships with each other, professional, political and personal relations across trajectories became denser in the 1980 s. Actors and organizations situated within different trajectories began to consistently cooperate and interact. A landmark moment for the emergence of new pro-indigenous organizations and the intensification of linkages among actors situated in different trajectories was the anti-emancipation mobilizations of the late 1970s. For example, in 1978 an enormous anti-emancipation rally was held in São Paulo, welcoming prominent lawyers, sociologists, linguists and anthropologists into the pro-indigenous struggle. The mobilizations were successful in three ways: they led the government to suspend emancipation, drove the expansion of pro-indigenous organization and resulted in the assertive appropriation of the law - and of the very meaning of tutorship - by the indigenous movement. These culminated in the consolidation of a national field of indigenous support organizations and in a broad-based inter-sectoral rally in São Paulo, which in 1978 brought together missionaries, episcopates, anthropologists, lawyers, doctors and others in a movement for the defense of indigenous rights. This event, in turn, placed indigenous struggles at the center of Brazil's emerging pro-democracy mobilizations, providing it with institutionalized support and visibility in the large urban centers of the country.

The figures below illustrate the sequencing of these two mechanisms in the formation of a national pro-indigenous social movement in Brazil. Figure 1 shows how transnational mobilization converged into an increasingly dense and diverse field of proindigenous organizations operating within the country throughout the late 1970s. Figure 2 illustrates how actors situated across different trajectories activated the partial outcomes generated within parallel pathways to advance their mobilization.

Figure 1. Multi-level mobilization, social networking and the formation of a national pro-indigenous movement

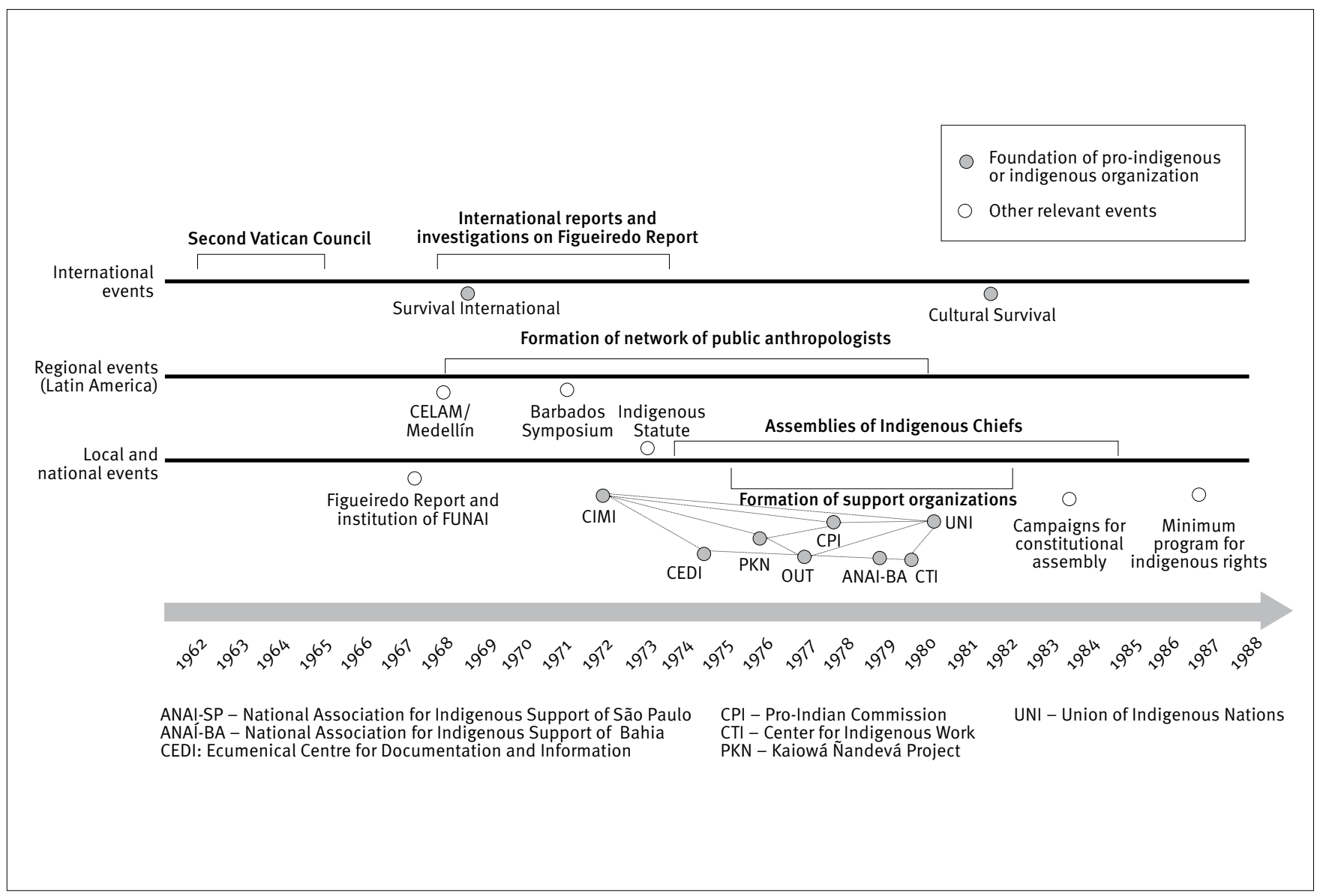


Figure 2. Institutional cross-referencing in the formation of a national pro-indigenous movement

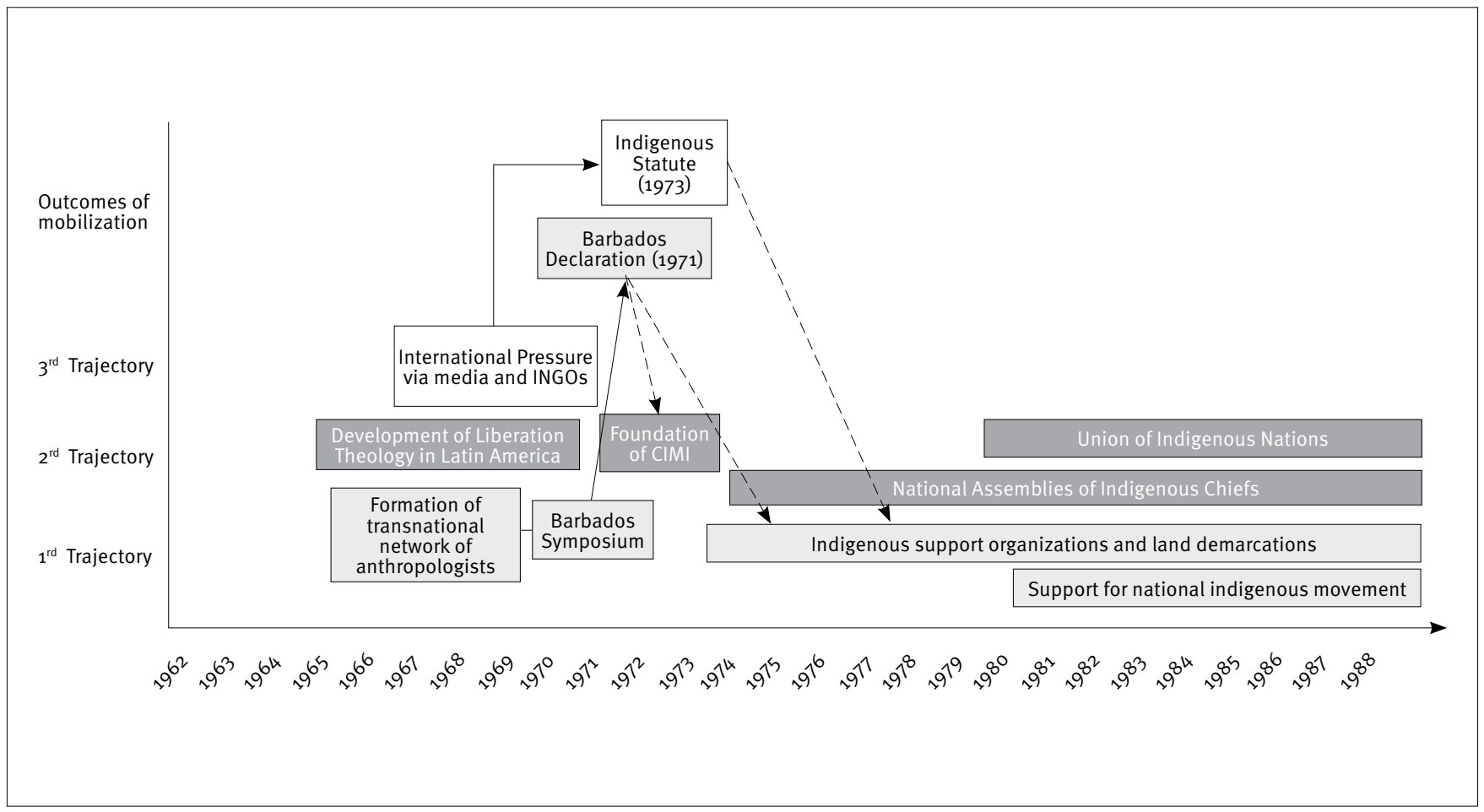

Throughout the early and mid-1980, the Catholic missionaries and the support organizations (which at this point were composed not only of anthropologists but also of lawyers, linguists, sociologists, and the like) consistently worked together in order to develop a broad positioning of the national indigenous movement at the Constitutional Assembly, which took place in 1987-1988. A series of symposiums and conferences were held in the mid-1980s in which actors from different trajectories participated. By this time, the Union of Indigenous Nations had the support of a number of support organizations, including CIMI, the Associação Brasileira de Antropologia (Brazilian Association of Anthropology [ABA]), the Comissão Pró-Índio de São Paulo (ProIndian Commission of São Paulo [CPI-SP]), the Central Unica Dos Trabalhadores (Centralized Worker's Union [CUT]), among others (Bicalho, 2011). In 1985, UNI formulated a Minimum Program for indigenous rights, to be proposed at the Constitutional Assembly. This program was developed by UNI and signed by 29 pro-indigenous organizations. Thus, by the time that the preparatory meetings for the National Constitutional Assembly were taking place, actors and organizations originally mobilizing along different trajectories had developed an increasing overlap and formed a national movement for indigenous rights. By the time the discussions about a new constitution were underway, a pro-indigenous movement, comprising actors and organizations from different sectors, was institutionalized in Brazil.

\section{CONCLUSIONS}

Through the study of transnational mobilization around indigenous rights over the course of two decades, this article explored how actors embedded in transnational networks and organizations drew on transnational linkages in order to generate ideational, organizational and institutional conditions for mobilization within unfavorable political contexts. Our longitudinal analysis contributes to the literature on transnational collective action by revealing previously unexplored trajectories of transnational activism and identifying two mechanisms through which initially uncoordinated trajectories of cross-border contestation converged into a coordinated and sustained process of mobilization - a social movement - embedded in domestic networks of contention and active predominantly within national political arenas. By analyzing these mechanisms, we render a more comprehensive account of how transnational collective action influences the formation of collective actors on national and local levels.

The three trajectories we described developed in the late 1960s and 1970s. They involved different actors and produced different partial outcomes. In the 1970s, they slowly converged by means of two mechanisms: institutional cross-referencing and social networking. On the one hand, actors situated in one trajectory picked up on the outcomes of other trajectories in order to forward their strategies and projects. On the other, the field of organizations involved in pro-indigenous activism became 
increasingly dense and intersectoral, and actors situated within different trajectories began to mobilize jointly. These enabled the convergence of multiple transnationally-linked trajectories of mobilization into one national movement. As the democratic transition advanced in Brazil, this national, intersectoral movement represented indigenous interests in a crucial moment of institution building and guaranteed important advances in the formalization of indigenous economic, cultural and political rights.

The activists situated within these trajectories were not exclusively local or global. While situated within local contexts and driven by their grounded experiences, both liberation theology missionaries and anthropologists were also part of transnational networks - such as the network of critical anthropologists - and institutions - such as the Catholic Church. Their simultaneous embeddedness in multiple spheres of engagement was crucial for the development of mobilization within each trajectory. Multiple embeddedness enabled activists to channel and adapt knowledge, projects and forms of organizing between levels of mobilization and to use the opportunities presented in one sphere of action to leverage capacity for mobilization in another.

These findings point to the importance of moving beyond analytical frameworks that emphasize the distinction between global and local actors, arenas and strategies in order to look more closely at the characteristics of the linkages that bridge across these levels of analysis. When it comes to creating local conditions for mobilization through transnational activism, the characteristics of such linkages - what flows through them, how diverse and connected they are - matter more than the positioning or location of actors within levels of action. More specifically, our findings suggest that two conditions were important for the emergence of a national pro-indigenous movement in Brazil in the late 1970 s and early 1980 s. First, the variety of trajectories of transnational mobilization was important because it resulted in a diversity or resources flowing between levels and in the generation of different partial outcomes of mobilization. The synergies between organizational, ideational and institutional outcomes were important for generating local conditions for mobilization, and none of the trajectories alone was able to generate these three conditions. Second, the outcomes of different trajectories must be available to and acknowledged by actors situated in different pathways so that they can draw on these outcomes and construct an overarching identity and coordinated strategies for the movement.

The variety of transnational linkages and the capacity to construct bridges across these linkages may be crucial for the emergence of sustained mobilization in other settings and contexts which seem unfavorable to social movements. In order to identify these processes, it is necessary, on the one hand, to shift from episodic to a historical analytical framework and, on the other, to focus more on the linkages that bridge across levels than on the positioning of actors and organizations involved in transnational contention.

\section{ACKNOWLEDGMENTS}

We would like to thank the anonymous reviewers as well as Jonathan Zeitlin for their helpful comments.

\section{REFERENCES}

Almeida, R. F. T. de. (2001). Do desenvolvimento comunitário à mobilização política: O Projeto Kaiowá-Ñandeva como experiência antropológica. Rio de Janeiro, RJ: Contra Capa Livraria.

Alonso, A. (2009). Hybrid activism: Paths to globalization in the Brazilian environmental movement. IDS Working Paper, 2009(332), 1-49. doi:10.1111/j.2040-0209.2009.00332_2.x

Bartolome, M. A, Batalla, G. B., Bonilla, H. D., Cardenas, G. C., Sardi, M. C. Grünberg, G... Varese S. (1971). Declaration of Barbados for the Liberation of the Indians. Symposium on Interethnic Conflict in South America, Bridgetown, Barbados.

Benites, T. (2014). Rojeroky hina há roike jevy tekohape (Rezando e lutando): O movimento histórico dos Aty Guasu dos Ava Kaiowá e Ava Guarani pela recuperação de seus tekoha. (Doctoral Thesis), Museu Nacional da Universidade Federal do Rio de Janeiro, RJ.

Bicalho, P. S. (2011). Protagonismo Indígena no Brasil: Movimento, cidadania e direitos (1970-2009). (Doctoral Thesis), Institute of Human Sciences of the National University of Brasília.

Bittencourt, L. B. (2007). A formação de um campo político na América Latina: Organizações indígenas no Brasil. Goiás, GP: Editoria UFG.

Boli, J., \& Thomas, G. M. (1999). Constructing world culture: International nongovernmental organizations since 1875 . Stanford, USA: Stanford University Press.

Brysk, A. (1993). From above and below: Social movements, the international system, and human rights in Argentina. Comparative Political Studies, 26(3), 259-285. doi:10.1177/0010414093026003001

Brysk, A. (2000). From tribal village to global village: Indian rights and international relations in Latin America. Stanford, USA: Stanford University Press.

Bülow, M. von. (2010). Building transnational networks: Civil society and the politics of trade in the Americas. Cambridge, UK: Cambridge Univesrity Press.

Cordeiro, A. (2013). Tutela e resistência indígena. São Paulo, SP: Editora da Universidade de São Paulo.

David, H. (2007). Transnational advocacy in the eighteenth century: Transatlantic activism and the anti-slavery movement. Global Networks, 7(3), 367-382. doi:10.1111/j.1471-0374.2007.00174.x

Davies, S. (1977). Victims of the miracle: Development and the Indians of Brazil. Cambridge, UK: Cambridge University Press. 
Der Spiegel. (1968, March 25). Arsen und Zuckerstückchen. Der Spiegel. Retrieved from http://www.spiegel.de/spiegel/print/d-46093905. html

Diacon, T. (2004). Strigning together a nation: Cândido Mariano Rondon and the construction of modern Brazil. Durham, UK: Duke University Press.

Djelic, M.-L., \& Quack, S. (2010). Transnational communities and governance. In M.-L. Djelic, \& S. Quack (Eds.). Transnational communities: Shaping global economic governance (pp. 3-36). Cambridge, UK: Cambridge University Press.

Ferguson, J. (2006). Global shadows: Africa in the neoliberal world order. Durham, UK: Duke University Press.

Figueiredo, J. (1967). Relatório Jader Figueiredo ao Ministro do Interior. Brasília, DF.

Garfield, S. (2001). Indigenous struggle at the heart of Brazil. Durham, UK: Duke University Press.

Gavarito, C. R. (2007). Sewing resistance: Transnational organizing, global governance, and labor rights in the US-Caribbean Basin apparel industry (1990-2005) (PhD thesis). University of WisconsinMadison, EUA.

Giugni, M. G. (1998). Was it worth the effort? The outcomes and consequences of social movements. Annual Review of Sociology, 24, 371-393. doi:10.1146/annurev.soc.24.1.371

Goodwin, J., \& Jasper, J. (1999). Caught in a winding, snarling vine: The structural bias of political process theory. Sociological Forum, 14(1), 27-54.

Grünberg, G. (2015, June 9). Interview with Ana Carolina Alfinito Vieira.

Heck, E. (2014, June 3). Interwiew with Ana Carolina Alfinito Vieira.

Keck, M., \& Sikkink, K. (1998). Activists beyond borders: Advocacy networks in international politics. Ithaca, USA: Cornell University Press.

Latin American Episcolal Council. (1968). Second general conference of the bishops of Latin America: Conclusions of Medellín. Medellin, Colombia.

Lewis, N. (1969, February). Genocide. The Sunday Times Magazine, 34-48.

Lima, A. C. de S. (1995). Um grande cerco de paz: Poder tutelar, indianidade e formação do estado no Brasil. Petrópolis, RJ: Vozes.

Matsuzawa, S. (2011). Horizontal dynamics in transnational activism: The case of $\mathrm{Nu}$ River anti-dam activism in China. Mobilization: An International Quartely, 16(3), 369-387. doi:10.17813/ maiq.16.3.30242741826ko5r2

Mayntz, R. (2004). Mechanisms in the analysis of social macrophenomena. Philosophy of the Social Sciences, 34(2), 237-259.
Meyer, D. (2003). Political opportunities and nested institutions. Social Movement Studies, 2(1), 17-35. doi:10.1080/1474283032000062549

Montgomery, P. (1968, March 21). Killing of Indians Charged in Brazil. The New York Times.

Oliveira, J. P. de. (1985). Contexto e horizonte ideológico: Reflexões sobre o Estatuto do Índio. In S. C. dos Santos et al. (Eds.). Sociedades indígenas e o direito: Uma questão de direitos humanos. Florianópolis, SC: Editora da UFSC.

Oliveira, R. C. (1988). A crise do indigenismo. Campinas, SP: Editora da Unicamp.

Prezia, B. (2003). Caminhando na luta e na esperança: Retrospectiva dos últimos 60 anos da pastoral indigenista e dos 30 anos do CIMI. São Paulo, SP: Loyola.

Ribeiro, D. (1970). Os índios e a civilização. São Paulo, SP: Companhia das Letras.

Risse, T., \& Sikkikk, K. (1999). The power of human rights: International norms and domestic change. Cambridge, UK: Cambridge University Press.

Schneiberg, M. (2007). Whats on the path? Path dependence, organizational diversity and the problem of institutional change in the U.S. economy, 1900-1950. Socio-Economic Review, 5(1), 47-80. doi:10.1093/ser/mwloo6

Schneiberg, M., \& Lounsbury, M. (2008). Social movements and institutional analysis. In R. Greenwood, C. Oliver, K. Sahlin, \& R. Suddaby (Eds.), The Sage handbookoforganizational institutionalism (pp. 650-672). London, UK: Sage.

Silva, M. A. da. (2012). Entrevista com Antonio Jacó Brand. Revista Tellus, 12(23), 179-192.

Smith, C. (1991). The Emergence of liberation theology: Radical religion an social movement theory. Chicago: University of Chicago Press.

Stark, D., Vedres, B., \& Bruszt, L. (2006). Rooted transnational publics: Integrating foreign ties and civic activism. Theory and Society, 35(3), 323-349. doi:10.1007/s11186-006-9007-8

Suess, P. (1989). A causa indígena na caminhada e a proposta do CIMI (1972-1989). Petrópolis, RJ: Vozes.

Tarrow, S. (2005). The new transnational activism. Cambridge, UK: Cambridge University Press.

Tarrow, S., \& McAdam, D. (2005). Scale shift in transnational contention. In D. D. Porta, \& S. Tarrow (Eds.), Transnational protest and global activism (pp. 121-150). New York, USA: Rowman \& Littlefield.

Warren, J. (2001). Racial Revolutions: Antiracism and Indian resurgence in Brazil. Durham and London: Duke University Press.

Zajak, S. (2014). Pathways of transnational activism: A conceptual framework [Working Paper $\mathrm{N}^{\circ}$ 5]. MPIfG. 